\title{
Optimal acidulated phosphate fluoride gel etching time for surface treatment of feldspathic porcelain: on shear bond strength to resin composite
}

\author{
Boonlert Kukiattrakoon ${ }^{1}$
}

Kewalin Thammasitboon²

\section{ABSTRACT}

Objectives: This in vitro study evaluated the shear bond strength (SBS) of resin composite to feldspathic porcelain after acidulated phosphate fluoride (APF) gel treatment over different periods of time.

Methods: One hundred and fifty-six feldspathic specimens were divided into 12 groups. Group C received no treatment (control group). Groups APF1 through APF10, ten experimental groups, were treated with $1.23 \%$ APF gel. Each group obtained 1 to 10 minutes of etching time in 1 minute increments, respectively. Group HF2 was treated with $9.6 \%$ hydrofluoric acid (HF) for 2 minutes. All specimens were then bonded to a resin composite cylinder using Adper Scotchbond Multi-purpose (3M ESPE) after silane (Monobond-S, Ivoclar Vivadent AG) application. Specimens were stored at $37^{\circ} \mathrm{C}$ for 24 hours before the SBS was performed and were recorded in MPa at fracture. Data were analyzed using one-way ANOVA and Tukey's test ( $a=.05)$.

Results: HF etching yielded the highest SBS (18.0 $\pm 1.5 \mathrm{MPa}$ ), which was not significantly different from APF gel etching for 6 to 10 minutes $(16.0 \pm 2.1$ to $17.2 \pm 1.6 \mathrm{MPa})(P>.05)$.

Conclusions: APF gel etching for 6 minutes might be used as an alternative etchant to HF acid for bonding resin composite to silanized feldspathic porcelain. (Eur J Dent 2012;6:63-69)

Key words: Bond strength; feldspathic porcelain; resin composite; acidulated phosphate fluoride gel.

1 Prince of Songkla University, Faculty of Dentistry Dental Materials Research Unit, Hat Yai, Songkhla, Thailand

2 Prince of Songkla University, Faculty of Dentistry, Department of Conservative Dentistry, Hat Yai, Songkhla, Thailand.

- Corresponding author: Dr. Boonlert Kukiattrakoon Prince of Songkla University, Faculty of Dentistry, Department of Conservative Dentistry, 15 Kanchanavanich, Hat Yai, Songkhla, Thailand

Phone: + 6674287703 Fax: + 6674429877

E-mail: boonlert.kapsu.ac.th

\section{INTRODUCTION}

Feldspathic porcelain, used in porcelain-fusedto-metal restoration, possesses several favorable physical properties including high flexural strength ( 60 to $70 \mathrm{MPa}$ ), high resistance to compression, resistance to wear, and aesthetic properties, which make it possible to imitate the color, reflectivity, and translucency of natural teeth. It also has a high resistance to dissolution in the oral cavity and possesses low thermal and electrical conduc- 
tance. ${ }^{1-3}$ However, all kinds of porcelain, including feldspathic porcelain, are brittle and highly susceptible to breakage caused by, for example, extensive occlusal force, poor metal substructure design, flexural fatigue of the metal substructure, or insufficient porcelain thickness. ${ }^{4,5}$ Consequently, after dental caries, porcelain fractures have been reported as the second most common reason for restoration replacement. ${ }^{4}$ Dentists usually search for various methods of prolonging the service life of existing restorations, since restoration replacement can lead to further damage to teeth and additional costs for patients. Repairing the fractured porcelain with resin composite is the most commonly used method for this task. Resin composite is relatively inexpensive, easy to manipulate, ${ }^{6}$ and the properties of currently available resin composite materials are continuously being improved.

Etching with hydrofluoric (HF) acid is a well accepted pre-treatment for preparing porcelain surfaces for resin composite bonding. ${ }^{7} \mathrm{HF}$ acid, at low concentrations, firstly assaults the leucite crystals $\left(\mathrm{K}_{2} \mathrm{O} \cdot \mathrm{Al}_{2} \mathrm{O}_{3} \cdot 4 \mathrm{SiO}_{2}\right)$, the crystalline component of feldspathic porcelain, followed by undissolved feldspar silica. The next composition to counter is the glassy matrix or silica phase, followed by alumina, if impart. $8,9 \mathrm{HF}$ acid reacts selectively with the silica phase to form hexafluorosilicates in the rate of 0.44 micron/minute, creating a microretentive surface which facilitates the interlocking of the resin composite. ${ }^{8} \mathrm{HF}$ acid is very effective in porcelain-surface etching. Previous studies have shown that HF acid treatment produced statistically higher bond strengths did than other types of surface treatments. ${ }^{10,11}$ Some studies have demonstrated that the bond strength between the resin composite and $\mathrm{HF}$ acid etched-porcelain is significantly increased by silanization..$^{12,13}$ Nonetheless, Aida et $\mathrm{al}^{14}$ found no difference in bond strength, after silane application, between polished porcelains and those etched with HF acid. This corresponds with other studies $^{15,16}$ in which the formation of a siloxane bond was shown to be more important than the micromechanical retention produced by etching. The suggested etching time for feldspathic porcelain with $\mathrm{HF}$ acid is 2 to 2.5 minutes. ${ }^{17}$ Even though $\mathrm{HF}$ acid is an effective etching agent for porcelain surface treatment, it is considered a hazardous agent which can produce tissue rash and burn. ${ }^{18} \mathrm{HF}$ acid diffuses into cells and kills them by disrupting their metabolism. When HF acid is spilled onto skin, it can cause burns, which often result in deep tissue necrosis. During the intra-oral use of HF acid for porcelain-surface treatment, special precautions should be taken. Thus several studies have suggested that HF acid etching of ceramic surfaces is not an appropriated intraoral method for repairing fractured ceramic restorations. ${ }^{19-22}$ For this reason, $1.23 \%$ acidulated phosphate fluoride (APF) gel, which is weaker than HF acid, is used as an alternative etchant. 9,23

Previous studies have reported that surface treatment of silanized feldspathic porcelain, for bonding with resin composite, with $9.5 \% \mathrm{HF}$ acid for 424 to 525 minutes was comparable to treat with $1.23 \%$ APF gel for 10 minutes. Another study by Brentel et $\mathrm{al}^{13}$ demonstrated that etching unsilanized feldspathic porcelain with $10 \% \mathrm{HF}$ acid was comparable to etch with $1.23 \%$ APF gel for 5 minutes. However, these studies have not revealed the scientific reason why these etching time of APF gel were used; and 5 or 10 minutes etching with APF gel is relatively time consuming compared with HF acid etching. It would be more beneficial to the patient if the etching time of APF gel, which serves as a safe and effective substitute for etching porcelain surfaces, could be shortened.

The present study aimed to investigate the effect of various APF gel etching time upon the shear bond strength of resin composite on feldspathic porcelain to achieve the optimal time, and to characterize the topographic changes of porcelain surfaces after the treatments. The null hypothesis test was that there was no difference in the shear bond strength of resin composite to feldspathic porcelain yielded from etching with APF gel and with HF for different periods of time.

\section{MATERIALS AND METHODS}

The materials used in this study and their compositions are shown in Table 1. One hundred and fifty-six specimens were prepared according to the manufacturer's instruction. Briefly, feldspathic porcelain powder (VMK 95, Shade A3 dentin, Vita Zahnfabrik, Bad Säckingen, Germanyl was mixed with deionized water and condensed into a roundshaped silicone mold (Provil, Heraeus Kulzer, Wehrheim, Germany), $15 \mathrm{~mm}$ in diameter and $1.5 \mathrm{~mm}$ in height. The non-sintered mixture was left to dry for 2 minutes before being processed by heating to 
$600^{\circ} \mathrm{C}$ for 6 minutes in a vacuum furnace (Tru-Fire VPF, Jelenko, Armonk, NY, USA). The temperature was then increased by $38^{\circ} \mathrm{C} / \mathrm{min}$ to $960^{\circ} \mathrm{C}$, and held for 1 minute.

Feldspathic porcelain discs with less than $16 \%$ linear shrinkage after sintering las specified by ADA/ANSI specification No. 691 ${ }^{26}$ were included in the study. The average final diameter of the test specimens was $13.28 \mathrm{~mm}$ (13.40 to $14.16 \mathrm{~mm}$ ). The specimens were then polished (model Phoenix 4000, Buehler GmbH, Düsseldorf, Germany) under running water using 600- and 1,200-grit silicon carbide paper (3M ESPE, St. Paul, MN, USA). Subsequently, they were embedded in autopolymerizing clear acrylic resin (Takilon, Rodont srl, Milan, Italy), $20 \mathrm{~mm}$ in height and $30 \mathrm{~mm}$ in diameter. The specimens were divided into 12 groups of 10 specimens each. The surface treatments performed on each group were as follows: Group $C$ was the control group (no treatment); Groups APF1 to APF10 were etched with $1.23 \%$ APF gel (New Age Fluoride Gel, Pascal Co., Bellevue, WA, USA) (pH $3.5 \pm 0.5$ ) for 1 to 10 minutes, respectively; and Group HF2 was etched with 9.6\% HF acid (Porcelain Etch Gel, Pulpdent Corp., Watertown, MA, USA) for 2 minutes. All specimens in group HF2 and groups APF1 to APF10 were rinsed with water for 20 seconds and air-dried for 30 seconds.

\section{Bonding procedures}

Prior to bonding with resin composite, the porcelain specimens were treated with silane solution (Monobond-S, Ivoclar Vivadent AG, Schaan, Liechtenstein) for 1 minute with a clean brush-1 layer was applied and then air-dried. A bonding agent (Adper Scotchbond Multi-Purpose Plus Adhesive, 3M ESPE) was applied and light-polymerized with visible light $1600 \mathrm{~mW} / \mathrm{cm}^{2}$ at a wavelength of 400 to $500 \mathrm{~nm}$; Translux EC, Heraeus Kulzer) for 20 seconds.

A thin plastic tube (AP Extrusion, Salem, $\mathrm{NH}$, USA) with $3 \mathrm{~mm}$ inner diameter and $2 \mathrm{~mm}$ thickness was positioned at the center of each porcelain specimen and the tube was held in place with plastic pliers fixed onto a metal lab stand. Resin composite (Filtek Z250, 3M ESPE) was filled in the tube and light-polymerized for 40 seconds, and again for 40 seconds after the plastic tube had been cut with a blade and removed. This resin composite was selected because, as a hybrid, it has been used for anterior and posterior tooth restorations as well as porcelain repair. ${ }^{27,28}$ It also presented to have good overall performances including good wear resistance, esthetics, and flexural strength..$^{29,30}$ Subsequently, all porcelain specimens were stored in $100 \%$ humidity at $37^{\circ} \mathrm{C}$ for 24 hours before testing.

\section{Shear bond strength testing}

The shear bond strength of resin composite on the porcelain specimens was tested by using a single-bladed Instron Machine (model 5583, Instron Corp., Norwood, MA, USAl at a crosshead speed of $0.2 \mathrm{~mm} / \mathrm{min}^{31}$ (Figure 1). The load at failure was recorded and converted to shear bond strength expressed in MegaPascals (MPa), as a following formula:

Shear bond strength $=\mathrm{F} / \Pi \mathrm{r}^{2}$

where $F$ is a load force at fracture in Newtons, and $r$ is a radius of the resin composite cylinder in meters. The surfaces of the specimens were subsequently examined under a stereoscope (model SMZ 1500m, Nikon Instech, Kanagawa, Japan) at $\times 40$ magnification, in order to determine the mode of failure. Mode of failure was recorded by one observer as either adhesive (between porcelain or resin composite and bonding agent), cohesive (in the porcelain, resin composite or bonding agent) or a combination of adhesive and cohesive fractures.

Surface topography analysis

To investigate the etched surface topography, 36 porcelain specimens-three from each groupwere selected. The specimens were rinsed with distilled water for 20 seconds, dried, and mounted onto aluminium stubs $113 \mathrm{~mm}$ diameter and $10 \mathrm{~mm}$ height). Consequently, specimens were sputter-coated with a gold-palladium alloy (SPIModule sputter, SPI Supplies, West Chester, PA, USA). Observations were made under a scanning electron microscope (SEM) (model JSM-5800LV, JEOL, Tokyo, Japan) at $\times 2000$ magnification.

\section{Statistical analysis}

Data were statistically analyzed. A one-way analysis of variance (ANOVA) was used to find differences between groups. Tukey's Honestly Significant Difference (HSD) Test was used for post hoc comparisons ( $a=.05)$. 


\section{RESULTS}

Results of the one-way ANOVA revealed that the shear bond strength differed significantly between groups $(P<.001)$. The mean values of the shear bond strength of resin composite on the porcelain at the fracture, as well as the results of multiple

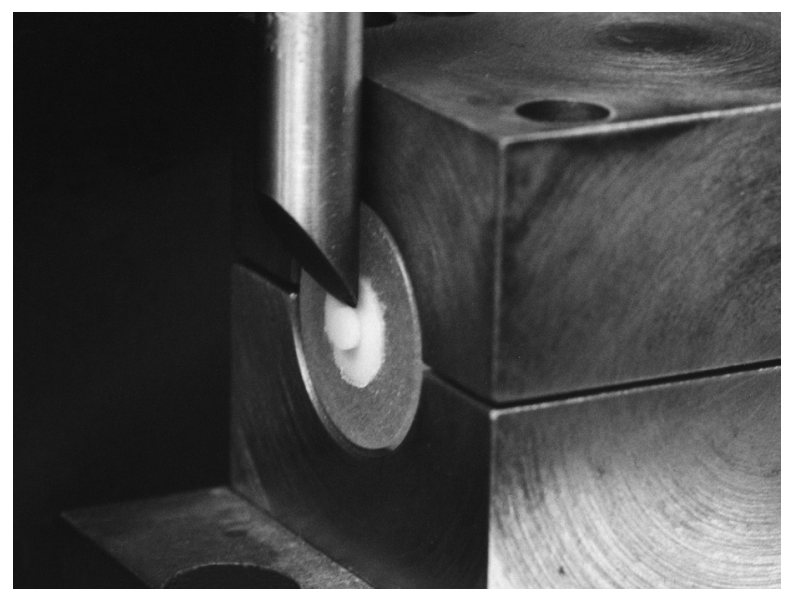

Figure 1. Shear bond strength testing.

Table 1. Material used in this study.

\begin{tabular}{|c|c|c|c|}
\hline Product & Description and composition (wt\%) & Batch no. & Manufacturer \\
\hline Vita VMK95 & $\begin{array}{l}\text { Feldspathic porcelain, SiO2 52-68\%, Al2O3 14-19\%, K20 } \\
\qquad 10-13 \%\end{array}$ & 7530 & Vita Zahnfabrik, Bad Sackingen, Germany \\
\hline Filtek Z250 & $\begin{array}{c}\text { Zirconia/silica 100\%, BisGMA, UDMA, BisEMA, Cam- } \\
\text { phorquinone }\end{array}$ & $6 \mathrm{CW}$ & 3M ESPE, St. Paul, MN, USA \\
\hline New Age Fluoride & $\begin{array}{l}\text { Fluoride ion } 1.23 \%( \pm 0.1 \%) \text { from sodium fluoride, phos- } \\
\text { phoric acid added to } \mathrm{pH} 3.5( \pm 0.5)\end{array}$ & 51309 & Pascal, Bellevue, WA, USA \\
\hline Porcelain Etch Gel & Hydrofluoric acid gel $9.6 \%$ & 971218 & Pulpdent Corp, Watertown, MA, USA \\
\hline Monobond-S & $\begin{array}{l}\text { Silane coupling agent, 3-methacryloxypropyl-trime- } \\
\text { thoxysilane } 1 \% \text {, water and ethanol } 99 \% \text {, acetic acid }\end{array}$ & B3555 & Ivoclar-Vivadent AG, Schaan, Liechtenstein \\
\hline $\begin{array}{l}\text { Adper Scotchbond Plus } \\
\text { adhesive }\end{array}$ & BisGMA $60-70 \%, 2$-hydroxyethylmethacrylate $30-40 \%$ & 6PM & 3M ESPE, St. Paul, MN, USA \\
\hline
\end{tabular}

BisGMA: Bisphenol-glycidyl methacrylate; UDMA: Urethanethyl dimethaacrylate; BisEMA: Bisphenol-polyethylene glycol dimethacrylate.

Table 2. Mean shear bond strength (MPa) and standard deviation (SD) of feldspathic porcelain to resin composite and the results of statistical tests.

\begin{tabular}{|c|c|c|c|c|}
\hline \multirow{2}{*}{ Groups } & \multicolumn{2}{|c|}{ Surface treatment } & \multirow{2}{*}{ Mean \pm SD (MPa) } & \multirow{2}{*}{ Tukey group* } \\
\hline & Agent & Etching time (min) & & \\
\hline C & No treatment & 0 & $6.48 \pm 1.18$ & A \\
\hline APF1 & $1.23 \%$ APF gel & 1 & $10.91 \pm 1.11$ & B \\
\hline APF2 & $1.23 \%$ APF gel & 2 & $11.98 \pm 1.11$ & $\mathrm{~B}$ \\
\hline APF3 & $1.23 \%$ APF gel & 3 & $12.09 \pm 1.07$ & $\mathrm{~B}$ \\
\hline APF4 & $1.23 \%$ APF gel & 4 & $13.81 \pm 1.59$ & C \\
\hline APF5 & $1.23 \%$ APF gel & 5 & $15.29 \pm 1.77$ & C \\
\hline APF6 & $1.23 \%$ APF gel & 6 & $16.05 \pm 2.07$ & $\mathrm{D}$ \\
\hline APF7 & $1.23 \%$ APF gel & 7 & $16.19 \pm 1.87$ & $\mathrm{D}$ \\
\hline APF8 & $1.23 \%$ APF gel & 8 & $16.39 \pm 1.58$ & $\mathrm{D}$ \\
\hline APF9 & $1.23 \%$ APF gel & 9 & $16.77 \pm 1.55$ & $\mathrm{D}$ \\
\hline APF10 & $1.23 \%$ APF gel & 10 & $17.17 \pm 1.58$ & $\mathrm{D}$ \\
\hline HF2 & 9.6\% HF acid & 2 & $18.01 \pm 1.55$ & $D$ \\
\hline
\end{tabular}

SD: standard deviation.

*Groups designated by different letters were significantly different $(P<.05)$. comparisons using Tukey's HSD tests, are presented in Table 2. Group HF2 showed the highest mean and standard deviation (SD) value of shear bond strength (18.01 $\pm 1.55 \mathrm{MPa})$. These results did not statistically differ from those in the case of groups APF6 to APF10 ( $P>$.05). The control group showed the lowest mean shear bond strength $16.48 \pm 1.19$ $\mathrm{MPa}$. Overall, the shear bond strength yielded from the specimens etched with $1.23 \%$ APF gel increased as the etching time increased. There was a significant difference observed among groups APF1 to APF 3, and groups APF4 to APF5 (P>.05).

SEM images of the differently treated porcelain surfaces are shown in Figure 2. Surfaces of the specimens in the control group were generally smooth. Fine scratches and grooves were observed (Figure 2A). HF acid etching (Figure 2L) produced obvious topographical alterations on the porcelain, in which irregular porous surfaces with numerous
European Journal of Dentistry 
microundercuts were observed over the entire surface. All specimens treated with APF gel for various periods of time were similar to each other in surface topography, being multiple agglomerate structures and large irregular areas surrounded by multiple small pits (Figures 2B through 2K). APF etching created pits that were homogenous in size, depth, and shape.

The mode of failure of all specimens, evaluated under a stereoscope, was found to be adhesive failure at the porcelain and bonding agent interface.

\section{DISCUSSION}

Etching with HF acid or APF gel is a common procedure used to create a microretentive sur- face prior to repairing porcelain restorations with resin composite. In the present study, the results revealed that $1.23 \%$ APF gel etching for at least 6 minutes could be used as an alternative etchant to HF acid, which is considered to be a hazardous agent. Interestingly, surface analyses of HF acid and APF gel etched porcelain have revealed the production of markedly different etching patterns. APF gel etching produced minimal surface roughness. It produced only a few shallow pores and undercuts, whereas the samples etched with HF acid showed greater roughness and irregularity. These results supported the study by al Edris et al, ${ }^{32}$ which showed no correlation between the surface roughness of porcelain and the bond strength of resin

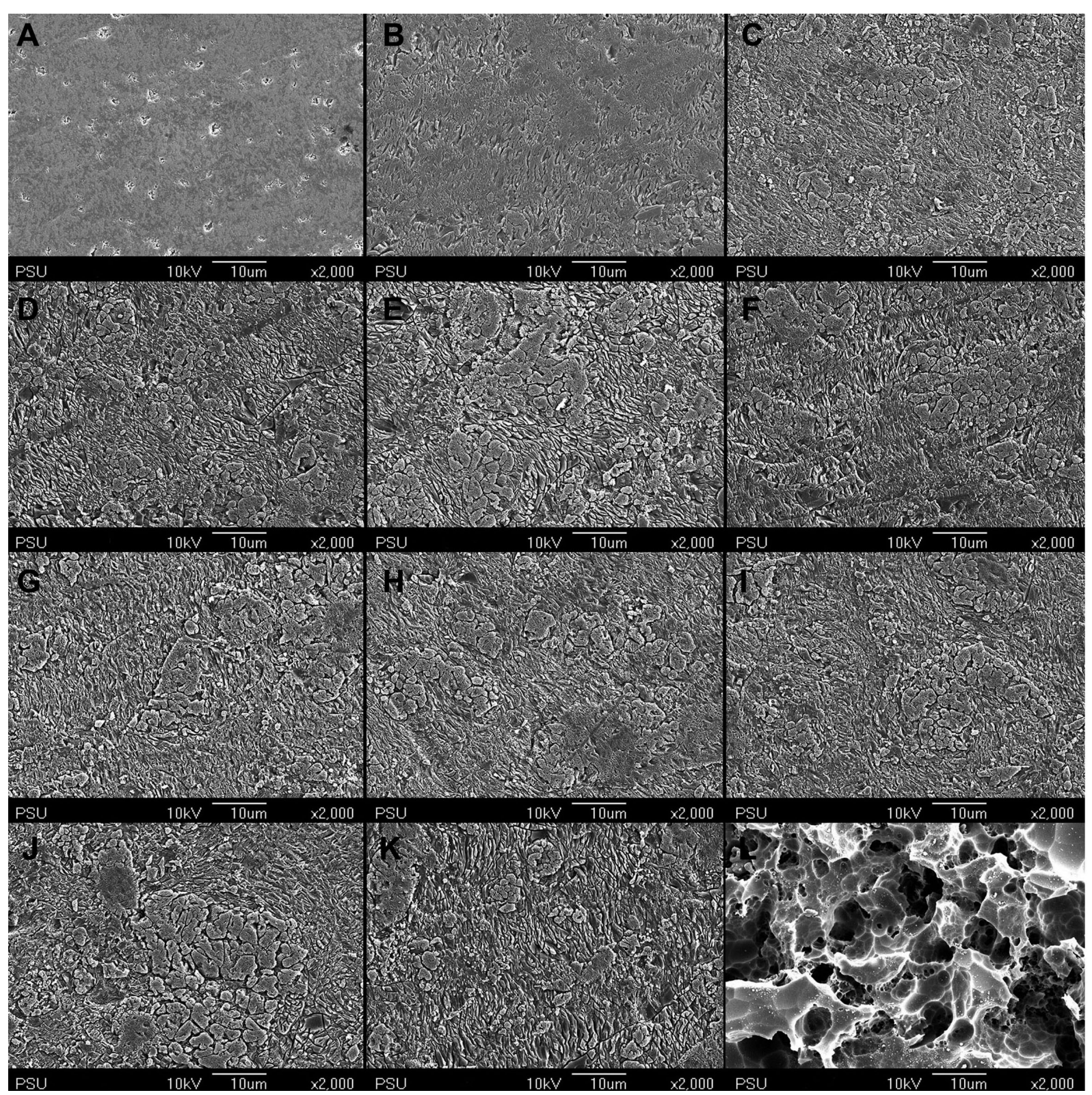

Figure 2. SEM results of porcelain specimens (original magnification $\times 2000$ ). A- Control group, B- through K- Etching with $1.23 \%$ APF gel for 1 to 10 minutes, respectively, L- Etching with $9.6 \% \mathrm{HF}$ acid for 2 minutes. 
composite to the etched porcelain. Nevertheless, the results in this present study seemed to imply that roughness of the etched porcelain surface, to a certain extent, should influence shear bond strength because only groups APF6 to APF10 provided a comparable bond strength to group HF2. SEM photomicrographs, in visual observations, also appear as if roughness increasing is a function of etching time.

These present findings suggest the hypothesis that shear bond strength, to some degree, is determined not only by surface roughness but also by other factors. A factor that could possibly affect bond strength is silanization. It has been shown that silane treatment significantly increases bond strength especially when the porcelain has been previously etched with HF acid. ${ }^{13,24}$ Silanization has also been shown in several studies to be an even more important step than acid etching. . $^{14-16}$ These findings may explain the level of shear bond strength (6.48 $\pm 1.18 \mathrm{MPa})$ observed in the control group (no surface treatment) in the present study. Surface roughness and silanization were also possible reasons for ascribing that roughnesses of feldspathic porcelain after APF gel etching for 5 minutes or less did not achieve appropriate conditions, even when combined with silane treatment.

In this present study, a considerably high shear bond strengths between resin composite and porcelain was found in all groups, which corresponded with the findings of previous studies. ${ }^{13,24,25}$ In a study by Brentel et $\mathrm{al}^{1}{ }^{13}$ in which different etchants were used, and tested on microtensile bond strength, results showed that etching unsilanized feldspathic porcelain with $10 \% \mathrm{HF}$ acid for 1 minute was comparable to etching with $1.23 \%$ APF gel for 5 minutes. Meanwhile for silanized feldspathic porcelain, HF acid produced a significantly greater bond strength than did APF gel. The present study seemed to confirm by scientific investigation that when etching with $1.23 \%$ APF gel for an extended period of time up to 6 minutes, the shear bond strength result was favorable to etching with $9.6 \% \mathrm{HF}$ acid for $2 \mathrm{~min}$ utes.

Even though the most significant finding of this present study was that APF gel could be used as an alternative etchant, an in vitro study cannot exactly reproduce the environment of the oral cavity. The presence of water, proteins, and minerals, and differences in $\mathrm{pH}$ levels and temperature changes can affect the bond strength of resin composite on porcelains. Furthermore, several porcelain surface treatments other than silanization and acid etching are used clinically. These include roughening with a diamond rotary cutting instrument, treating with airborne-particle abrasion, and presently, laser irradiation. In this present study, only silane coupling treatment and acid etching were performed in order to exclude any effects of other preparations. Additionally, the present study demonstrated the results of only one type of porcelain and resin composite (Vita VMK95 and Filtek Z250 with Adper Scotchbond Multi-Purpose Plus Adhesive). Therefore, it should not be presumed that other types of porcelain and resin composite would demonstrate the same patterns of surface topography or bond strength. Further studies are required to elaborate upon those effects.

\section{CONCLUSION}

Within the limitations of this in vitro study, the values of bond strength between resin composite and feldspathic porcelains, yielded from 1.23\% APF gel etching for 6 to 10 minutes, were not statistically different from 9.6\% HF acid etching for 2 minutes. Therefore, APF gel might be used as a safe alternative etchant to HF acid.

\section{Acknowledgement}

This project was supported by the Faculty of Dentistry research fund, Prince of Songkla University.

\section{REFERENCES}

1. Giordano RA. Dental ceramic restorative systems. Compend Contin Educ Dent 1996;17:779-794.

2. Ozturk AN, Inan O, Inan E, Ozturk B. Microtensile bond strength of cad-cam and pressed-ceramic inlays to dentin. Eur J Dent 2007;1:91-96.

3. Malkoc MA, Sevimay M, Yaprak E. The use of zirconium and feldspathic porcelain in the management of the severely worn dentition: a case report. Eur J Dent 2009;3:75-80.

4. Latta MA, Barkmeier WW. Approaches for intraoral repair of ceramic restorations. Compend Contin Educ Dent 2000;21:635-646.

5. Turkaslan S, Tezvergil-Mutluay A. Intraoral repair of all ceramic fixed partial denture utilizing preimpregnated fiber reinforced composite. Eur J Dent 2008;2:63-68.

6. Noel LG, Mitchell WC. Porcelain veneer repair of prostheses. Gen Dent 1997;45:182-185. 
7. Stangel I, Nathanson D, Hsu CS. Shear strength of the composite bond to etched porcelain. J Dent Res 1987;66:14601465.

8. Yen TW, Blackman RB, Baez RJ. Effect of acid etching on the flexural strength of a feldspathic porcelain and a castable glass ceramic. J Prosthet Dent 1993;70:224-233.

9. Fitho AM, Vieira LC, Araújo E, Monteiro Júnior S. Effect of different ceramic surface treatments on resin microtensile bond strength. J Prosthodont 2004;13:28-35.

10. Della Bona A, Anusavice KJ, Hood JA. Effect of ceramic surface treatment on tensile bond strength to a resin cement. Int J Prosthodont 2002;15:248-253.

11. Chen JH, Matsumura H, Atsuta M. Effect of etchant, etching period, and silane priming on bond strength to porcelain of composite resin. Oper Dent 1998;23:250-257.

12. Kato $H$, Matsumura $H$, Ide T, Atsuta M. Improved bonding of adhesive resin to sintered porcelain with the combination of acid etching and a two-liquid silane conditioner. $J$ Oral Rehabil 2001;28:102-108.

13. Brentel AS, Özcan M, Valandro LF, Alarca LG, Amaral R, Bottino MA. Microtensile bond strength of a resin cement to feldspathic ceramic after different etching and silanization regimens in dry and aged conditions. Dent Mater 2007;23:1323-1331.

14. Aida M, Hayakawa T, Mizukawa K. Adhesion of composite to porcelain with various surface conditions. J Prosthet Dent 1995;73:464-470.

15. Shimada Y, Yamaguchi S, Tagami J. Micro-shear bond strength of dual-cured resin cement to glass ceramics. Dent Mater 2002;18:380-388.

16. Foxton RM, Pereira PN, Nakajima M, Tagami J, Miura H. Durability of the dual-cure resin cement/ceramic bond with different curing strategies. J Adhes Dent 2002;4:49-59.

17. Soares CJ, Soares PV, Pereira JC, Fonseca RB. Surface treatment protocols in the cementation process of ceramic and laboratory-processed composite restorations: a review. J Esthet Restor Dent 2005; 17:224-235.

18. Moore PA, Manor RC. Hydrofluoric acid burns. J Prosthet Dent 1982;47:338-339.

19. Shiu P, De Souza-Zaroni WC, Eduardo Cde P, Youssef MN. Effect of feldspathic ceramic surface treatments on bond strength to resin cement. Photomed Laser Surg 2007;25:291296.

20. Schmage P, Nergiz I, Herrmann W, Ozcan M. Influence of various surface-conditioning methods on the bond strength of metal brackets to ceramic surfaces. Am J Orthod Dentofacial Orthop 2003;123:540-546.

21. Kamada K, Yoshida K, Atsuta M. Effect of ceramic surface treatments on the bond of four resin luting agents to a ceramic material. J Prosthet Dent 1998;79:508-513.
22. Della Bona A, Anusavice KJ. Microstructure, composition, and etching topography of dental ceramics. Int J Prosthodont 2002;15:159-167.

23. Gau DJ, Krause EA. Etching effect of topical fluorides on dental porcelains: a preliminary study. J Can Dent Assoc 1973;39:410-415.

24. Lacy AM, LaLuz J, Watanabe LG, Dellinges M. Effect of porcelain surface treatment on the bond to composite. J Prosthet Dent 1988;60:288-291.

25. Tylka DF, Stewart GP. Comparison of acidulated phosphate fluoride gel and hydrofluoric acid etchants for porcelaincomposite repair. J Prosthet Dent 1994;72:121-127.

26. Council on Dental Materials, Instrument and Equipment. American National Standards Institute/American Dental Association Specification no. 69 Dental ceramics. Chicago, IL; American Dental Association; 1999.

27. Filho AM, Vieira LC, Araujo E, Monteiro Junior S. Effect of different ceramic surface treatments on resin microtensile bond strength. J Prosthodont 2004;13:28-35.

28. Guler AU, Yilmaz F, Yenisey M, Guler E, Ural C. Effect of acid etching time and a self-etching adhesive on the shear bond strength of composite resin to porcelain. J Adhes Dent 2006;8:21-25.

29. Narhi TO, Tanner J, Ostela I, Narva K, Nohrstrom T, Tirri T, Vallitu PK. Anterior Z250 resin composite restorations: one-year evaluation of clinical performance. Clin Oral Investig 2003;7:241-243.

30. Lohbauer U, von der Horst T, Frankenberger R, Kramer N, Petschelt A. Flexural fatigue behavior of resin composite dental restoratives. Dent Mater 2003;19:435-440.

31. Kukiattrakoon B, Thammasitboon K. The effect of different etching times of acidulated phosphate fluoride gel on the shear bond strength of high-leucite ceramics bonded to composite resin. J Prosthet Dent 2007;98:17-23.

32. al Edris A, al Jabr A, Cooley RL, Barghi N. SEM evaluation of etch patterns by three etchants on three porcelains. $J$ Prosthet Dent 1990;64:734-739. 